\title{
KESIAGAAN PAKAN PADA TERNAK SAPI SKALA KECIL SEBAGAI STRATEGI ADAPTASI TERHADAP PERUBAHAN IKLIM MELALUI PEMANFAATAN BIODIVERSITAS FLORA LOKAL
}

\section{THE FEED READINESS IN SMALL SCALE FARMS AS THE ADAPTATION STRATEGY TOWARD THE CLIMATE CHANGE BY EXPLOITING LOCAL FLORAL BIODIVERSITIES}

\author{
Maman Rahmansyah*, Arwan Sugiharto, Atit Kanti dan I Made Sudiana \\ Pusat Penelitian Biologi-LIPI, Cibinong Science Center, Jl. Raya Bogor Km. 46, Cibinong Bogor, 16911
}

\section{INTISARI}

Sumber daya flora lokal untuk pakan memiliki nilai penting, khususnya untuk ketahanan masyarakat petani di dalam menghadapi perubahan iklim global. Ketersediaan hijauan pakan untuk ternak pada ekosistem lahan kering tergantung kepada ketersedian air. Dampak perubahan iklim dirasakan pada bergesernya pola curah hujan, bahkan terhadap mulainya masa musim kering. Hal tersebut harus diantisipasi dengan kesiapan masyarakat lokal di dalam memahami ketersedian pakan dan pengelolaannya pada masing-masing musim. Di kawasan Bali Bagian Timur dan kawasan Nusa Tenggara (Barat dan Timur) iklim kering tahun 2004 menyebabkan krisis pakan. Mengacu kepada permasalahan tersebut di atas, penelitian telah dilakukan dengan tujuan inventarisasi sumberdaya hayati flora potensial di lahan kering. Fokus bahasan dilakukan berdasar kepada hasil survei dan pengumpulan data sekunder. Diperoleh 22 tanaman yang dapat dimanfaatkan untuk hijauan (forage feed) yang materialnya berlimpah pada musim hujan; sedangkan 15 ragam sumber pakan lainnya dapat dijadikan pakan awetan (silage) maupun pakan hijauan pada musim peralihan dan sepanjang musim kering. Hasil analisis menunjukkan bahwa saat ini yang perlu dilakukan adalah introduksi teknologi fermentasi silase untuk pengawetan pakan untuk persediaan musim kemarau. Terkait dengan pengembangan teknologi tersebut maka dilakukan kajian terhadap peran mikrobia penghidrolisis senyawa polimer dan proses fermentasi dengan keberadaan mikrobia GRAS (Generally Recognized as Safe) yang diawali oleh peran Lactobacillus plantarum. Hasil kajian dapat menjadi acuan dalam mengatasi dampak perubahan iklim di wilayah lahan kering, melalui aplikasi teknologi mikrobia fungsional pada pengelolaan pakan ternak sapi petani lokal yang berskala kecil.

(Kata kunci: Sumberdaya flora lokal, Iklim lahan kering, Pakan terfermentasi, Lactobacillus plantarum)

\section{ABSTRACT}

The presence of local floral resources as forage is essential, especially for the farm survival in anticipaty the impact of the global climate change. The availability of forage in the dry land ecosystems depends on water supply. However, the climate change has caused the change on rainfall pattern including the initiation of the dry season. The problem should be anticipated by the local farmers' readiness in providing sufficient feed and their ability in performing the excellent management during all seasons. In some areas of East Bali and Nusa Tenggara (West and East), dry climate crisis 2004 led to feed scarcity. Therefore, this study was conducted in order to identify the potential forage resources in the arid land. The discussion is focused on the results of survey and secondary data collection. Based on the results, there were 22 plants that could be used as forage which were abundant during rainy season, whereas 15 others were able to be forage and silage during the transitional season and along the dry season. The results also showed that the introduction of silage fermentation technique was required as the way to preserve feed for the supply during the dry season. In this study the role of polymer compounds hydrolyzing microbes and the fermentation process by the GRAS (Generally Recognized as Safe) microbes preceeded the role of Lactobacillus plantarum were observed. The results of this study may become a reference in anticipating the global climate change impacts in dry land areas by the application of functional microbial technology in small local farms' feed management activities.

(Key words: Local floral resources, Dry land climate, Fermented feed, Lactobacillus plantarum)

\footnotetext{
*Korespondesi (corresponding author):

Telp. +62 811118717

E-mail: manrakam@yahoo.co.id
} 


\section{Pendahuluan}

Strategi untuk meraih keberhasilan pada usaha ternak sapi memerlukan adanya asupan teknologi, pemberdayaan pada sisi pengelolaan (management), dan aspek pemuliabiakan (breed) ternak. Namun, faktor yang paling mengemuka di dalam kegiatan ternak sapi yang realistis adalah memberikan asupan pakan (feed) yang konsisten baik secara kuantitas maupun kualitas (Bamualim, 2011). Penguatan asupan pakan sering luput dari perhatian peternak kecil (petani) di pedesaan yang kepemilikan sapinya berkisar antara dua sampai lima ekor saja. Kegiatan beternak sapi sangat membantu usahatani mereka yang produktivitas lahannya rendah, selain kepemilikan lahannya pun relatif kecil. Keberadaan ternak sapi yang dimiliki petani di Indonesia secara keseluruhan jumlahnya relatif besar, oleh karena itu apabila diberdayakan dengan benar maka akan menjadi kekuatan nasional dan berkontribusi langsung terhadap Program Swasembada Daging Sapi sebagai program nasional untuk kemandirian daging tahun 2014 (Pusat Penelitian dan Pengembangan Peternakan, 2010).

Sumber pakan hijauan dapat diperoleh dari area hutan dan kebun, atau diusahakan melalui pola agroforestri. Sumber pakan limbah pertanian bisa langsung dikonsumsi ternak, dan tindak pengembangannya dapat dilakukan melalui proses ensilase. Pada teknologi ensilase dikenal proses secara biologi (silase) dan kimia (amonifikasi). Proses teknologi silase umumnya menggunakan mikrobia fungsional secara anaerob. Pakan fermentasi bisa memaksimalkan serapan pakan sehingga kenaikan bobot badan ternak menjadi lebih cepat. Penyusunan ransum dengan menggunakan hijauan sebagai bahan utama, kemudian dilengkapi dengan suplemen, dan penambahan aditif seperti probiotik maupun pemacu sintesis enzim seperti pro-vitamin, akan menjamin kecukupan nutrisi bagi ternak (Erowati, 2000; Mullik dan Permana, 2009).

Ketersediaan pakan baik yang berasal dari habitat alami maupun hasil kultivasi dipengaruhi oleh kondisi klimat. Pada musim penghujan ketersediaan hijauan sering melimpah, sedangkan pada musim kemarau menjadi kurang. Pada kondisi iklim yang normal, ritme ketersediaan pakan cenderung berimbang antara kebutuhan dan ketersediaannya di alam. Namun telah terjadi kecenderungan kebutuhan ternak yang jumlahnya terus meningkat, sedangkan pada sisi lain terjadi pergeseran pola iklim atau anomali cuaca yang mempengaruhi pola kehidupan flora. Dalam menghadapi perubahan tadi diperlukan strategi untuk meningkatkan daya adaptasi pada setiap komponen kehidupan di lingkungannya masing-masing. Tidak tersedianya bahan pakan dalam jumlah yang memadai karena keterbatasan lahan harus dipecahkan bersama untuk mendapatkan solusi (Risdiono et al., 2009; Murgueitioa et al., 2011; Janzen, 2011; Ukanwoko dan Igwe, 2012).

Agroekosistem merupakan suatu sistem yang menghasilkan komponen yang saling mendukung dan terintegrasi. Sistem tersebut sering dilakukan untuk mendukung suatu usaha ternak yang akan menghasilkan keuntungan tambahan karena diperoleh sumber pupuk organik dan limbah hasil panen tanaman sebagai sumber pakan. Konsep pertanian terintegrasi (integrated farming) menjadi lebih terukur karena memberikan input yang minimal dan output yang maksimal, selain menghasilkan siklus energi carbon yang singkat sehingga meminimalkan kemubadziran biomasa (Sumarsono, 2006; ACIAR SADI, 2009).

Merujuk pada kajian yang diuraikan tersebut maka fokus bahasan ditetapkan pada beberapa kegiatan yang meliputi inventarisasi sumberdaya hayati pakan lokal dengan mengumpulkan data primer dan sekunder di daerah pengamatan. Desiminasi teknologi, khususnya untuk eksploitasi sumberdaya mikrobia yang terkait dengan perbaikan pakan sapi untuk mengoptimalkan ketersediaan pakan berkualitas yang menunjang perolehan hasil. Kegiatan yang dilakukan juga bertujuan memberikan informasi pada lingkup kegiatan ternak sapi di dalam mengedepankan konsep adaptasi sehubungan dengan dampak perubahan iklim yang dapat berpengaruh kepada kegiatan perternakan sapi skala kecil di lingkup pedesaan.

\section{Materi dan Metode}

Fokus survei dilakukan di wilayah propinsi Bali (Jembrana dan Karangasem) dan Nusa Tenggara Timur (Kabupaten Timor Barat) selama periode Maret sampai Agustus 2012. Hasil inventarisasi biodiversitas flora sumber pakan merupakan deskripsi sampel lapangan dan diperbandingkan dengan sumber acuan dari referensi pustaka. Contoh kandang sapi skala kecil dibuat di Desa Yeh Sumbul, Kecamatan Yeh Embang, Kabupaten Jembrana, Bali.

Pakan silase dibuat dengan menggunakan bahan dasar tanaman jagung dan limbahnya (kulit buah dan tongkol) sebagai sumberdaya lokal yang melimpah, dan jerami padi dengan memanfaatkan inokulum Lactobacillus plantarum. Pembuatan contoh pakan dengan urutan seperti berikut: 1). Bahan segar dicacah dengan ukuran 1-2 cm, dilayukan dengan cara dijemur sampai kadar air mencapai $40-60 \%$ dari bobot segar, dengan bobot contoh bahan $5000 \mathrm{~g}$; 2). Bahan inokulum yang 
terdiri atas dedak halus $(250 \mathrm{~g})$, ditambah $100 \mathrm{ml}$ molases encer (10\%) dan $20 \mathrm{ml}$ biakan Lactobacillus plantarum hasil pembiakan di dalam fermentor yang berpopulasi $10^{9}$ per $\mathrm{ml}$ biakan disiapkan; 3). Inokulum dicampur (hasil poin-2) dengan bahan pakan secara merata, kemudian pakan ditempatkan di dalam wadah tertutup kedap udara selanjutnya diinkubasi; 4). Setelah pakan diinkubasi (minimal selama $3 \times 24$ jam), pakan siap diberikan ke ternak, atau dapat disimpan antara satu sampai enam bulan di dalam wadah kedap udara sehingga terjadi proses anaerob; 5). Pakan yang aman dikonsumsi beraroma segar dan warna tidak banyak berubah dari aslinya. Pakan yang gagal menjadi silase akan berbau busuk dan menghitam; 6). Analisis proksimat terhadap sampel pakan meliputi persentase kadar air, $\mathrm{pH}$, kadar abu, bahan kering, serat kasar, lemak kasar, neutral detergent fiber (NDF), acid detergent fiber (ADF), bahan ekstrak tanpa nitrogen (BETN), protein, protein kasar, total asam, kandungan kalsium $(\mathrm{Ca})$, dan fosfor $(\mathrm{P})$.

\section{Hasil dan Pembahasan}

\section{Tumbuhan sumber pakan}

Ketersediaan sumber pakan di lokasi survei umumnya dapat diperoleh dari hutan dan kebun sebagai bahan hijauan ternak (Tabel 1) yang digunakan sebagai pakan harian. Pemanfaatan lebih lanjut, bahan hijauan bisa dibuat silase sehingga dapat disimpan sebagai pakan awetan, khususnya untuk memanfaatkan kelimpahan sumber pakan pada musim penghujan. Bahan pakan bisa digunakan secara langsung, atau pada bahan pakan tertentu perlu diolah terlebih dahulu guna menghilangkan zat antinutrisi maupun yang dapat menimbulkan keracunan pada ternak (Salazar dan Jøker, 2001; Winugroho et al., 2009; Elevitch dan Thomson, 2006).

Wilayah yang keadaan tanahnya selalu dilanda kekeringan, sumber hijauan dari tanaman keras seperti pohon nangka (Elevitch dan Manner, 2006), mahoni, sengon, angsana (Joker, 2002; Thomson, 2006), gamal (Chadhokar dan Khantaraju, 1980), dan ketela karet (Akar, 1996) adalah hijauan yang biasa dimanfaatkan. Penanaman bibit (seedling) tanaman keras sebagai persediaan hijauan diperlukan pemilihan waktu dan tempat yang tepat mengingat tumbuhnya cukup lama. Penanaman pada awal musim hujan bertujuan supaya bibit yang baru tumbuh akan beradaptasi dan mudah mendapatkan air. Namun, penanaman dari stek batang lebih tepat dilakukan pada akhir musim penghujan untuk menghindari batang stek membusuk pada kondisi air terlalu berlimpah.

Pada musim kemarau, pakan diupayakan dari pemanfaatan limbah pertanian maupun sumber hijauan dari tanaman yang tahan kondisi kekeringan. Ketersediaan limbah jerami hasil panen padi, jagung, kacang tanah, kedelai, dan lainnya dapat dimanfaatkan sebagai sumber pakan secara langsung, atau melalui proses ensilase maupun amonifikasi. Hijauan dari tanaman leguminosa yang tahan kering dapat dimanfaatkan daunnya sebagai pakan segar (Fiana et al., 2004; Whistler dan Elevitch, 2006). Daftar limbah tanaman yang dapat dimanfaatkan pada awal dan selama musim kemarau tertera pada Tabel 2.

Kebutuhan pakan di daerah penelitian dapat dipenuhi dari lingkungan petani sendiri. Pemrosesan pakan hampir tidak dilakukan karena cukup dengan yang selama ini mereka lakukan. Kegiatan beternak sapi di kalangan petani lebih bersifat kegiatan sampingan. Pemanfaatan waktu lebih fokus kepada usaha bercocok tanam. Oleh karena itu kecepatan perbesaran ternak pun hanya mencapai $500 \mathrm{~g}$ per hari saja, dan itu merupakan kecepatan tumbuh yang minimal dimana sebetulnya masih bisa ditingkatkan.

Upaya untuk mengadopsi teknologi yang sederhana sekalipun di dalam memproses pakan adalah tindakan di luar kemampuan petani kecil pada umumnya. Kendalanya antara lain karena alokasi waktu dan kemampuan yang masih bersahaja untuk bertindak. Anggapan yang berkembang bahwa teknologi selain tidak praktis juga memerlukan biaya. Mereka perlu diyakinkan bahwa input teknologi dapat mendatangkan keuntungan. Solusinya diperlukan contoh kongkrit.

Teknologi yang mudah dicontoh dapat menimbulkan rangsangan kepada petani/peternak untuk meniru dan mengerjakannya. Sehubungan itu, kandang contoh yang dibangun di lokasi pengamatan untuk memelihara sapi skala kecil dijadikan percontohan dan berfungsi sebagai sekolah lapangan (Gambar 1) dalam teknik manajemen dan pemeliharaan ternak serta pusat informasi termasuk informasi terkait perubahan iklim dan adaptasi. Kotoran sapi dibuat kompos dan urine diolah menjadi bio-urine sebagai sumber pupuk tanaman. Lahan pendukung seluas $400 \mathrm{~m}^{2}$ dimanfaatkan seutuhnya untuk penyediaan pakan dan budidaya hortikultur. Kandang percontohan dibangun di Desa Yeh Sumbul, Kecamatan Yeh Embang, Kabupaten Jembrana, Bali.

\section{Sinergi dengan program pemerintah daerah}

Kegiatan ternak sapi di wilayah Propinsi Bali dibina melalui program Sistem Pertanian Terintegrasi (SIMANTRI) yang telah dirintis sejak 2009. Konsekuensinya setiap tahun akan selalu terjadi peningkatan kebutuhan lahan untuk penyediaan pakan. Penambahan produksi pakan menjadi tanggungjawab langsung petani yang tidak 


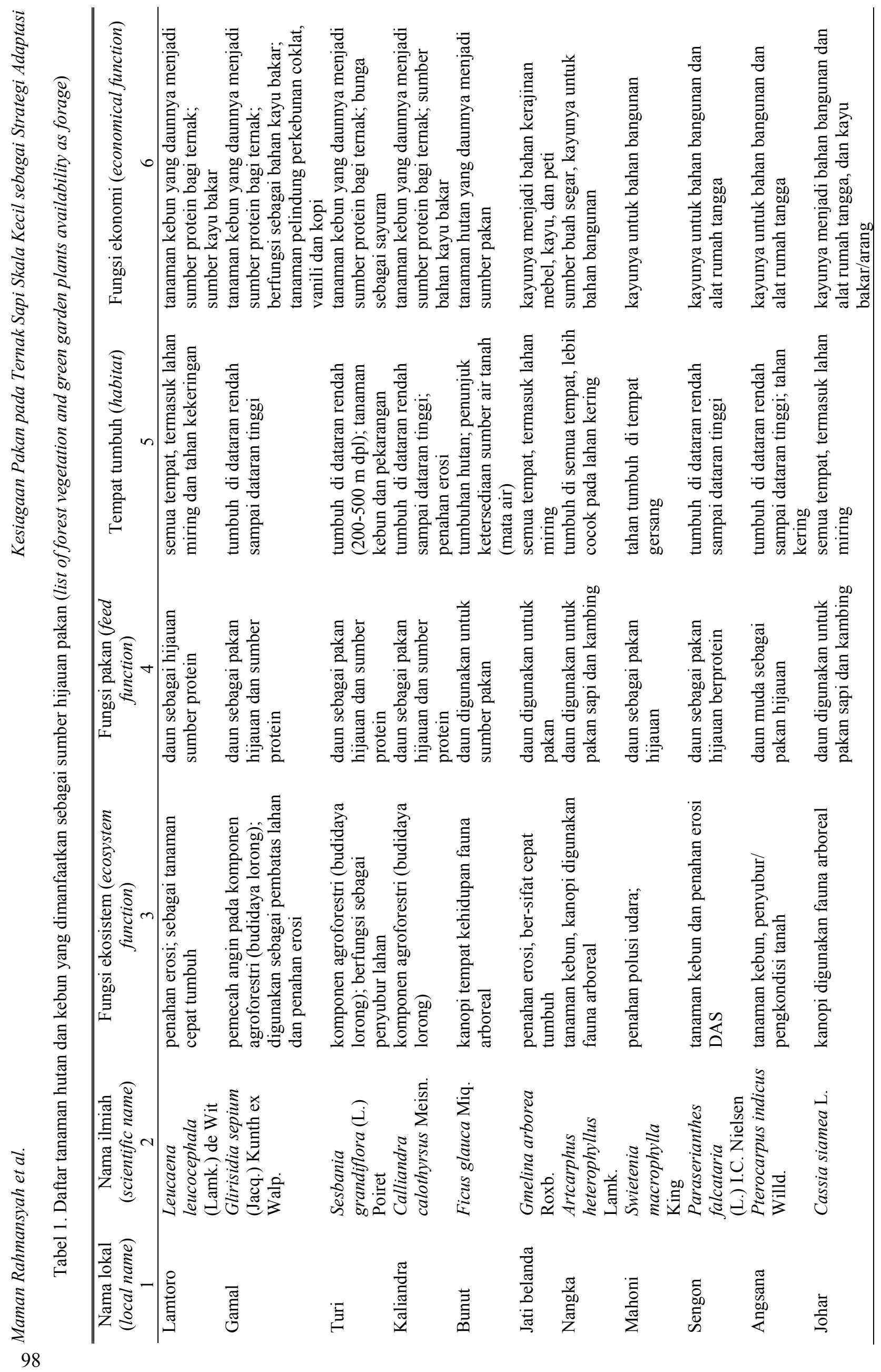




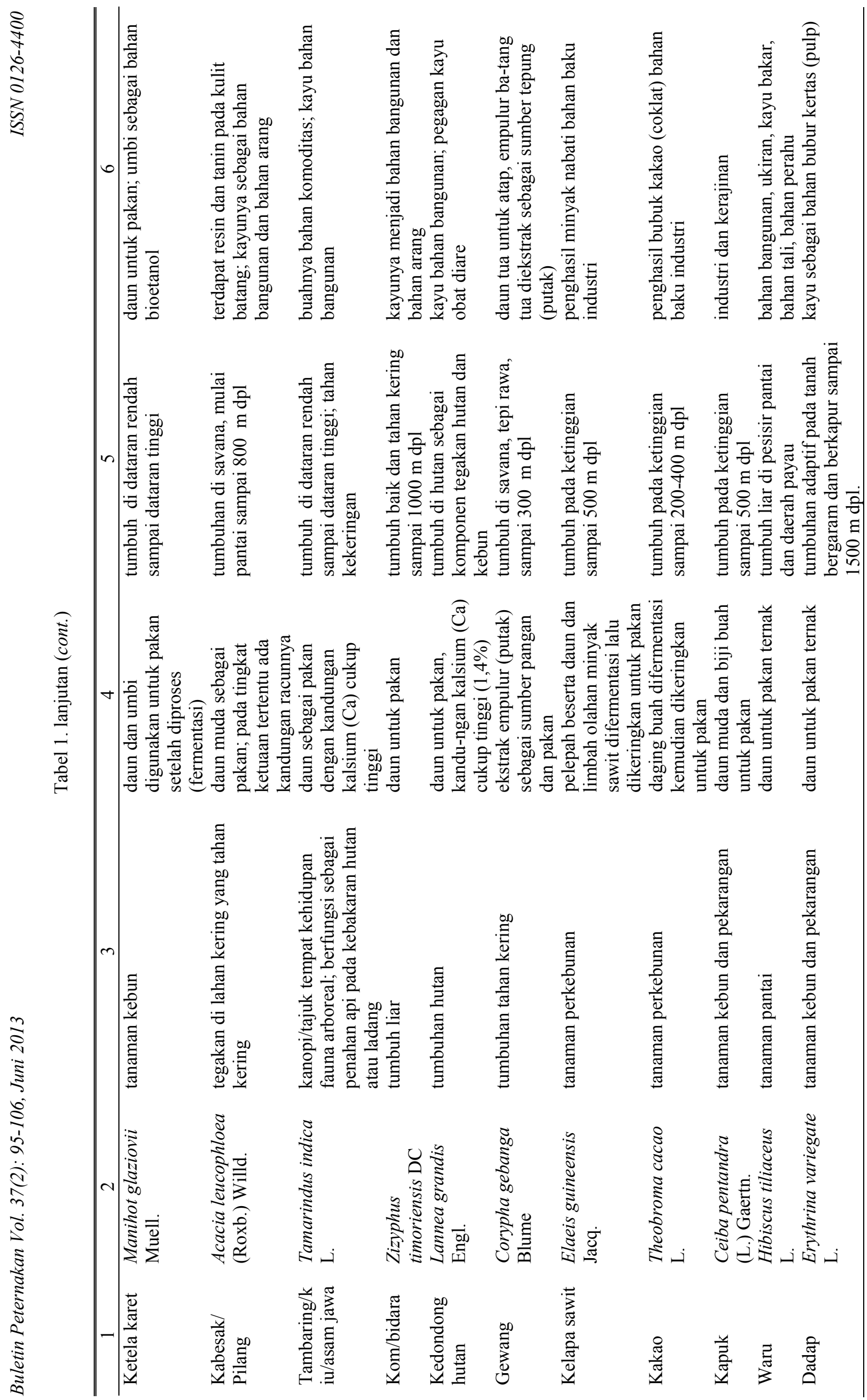




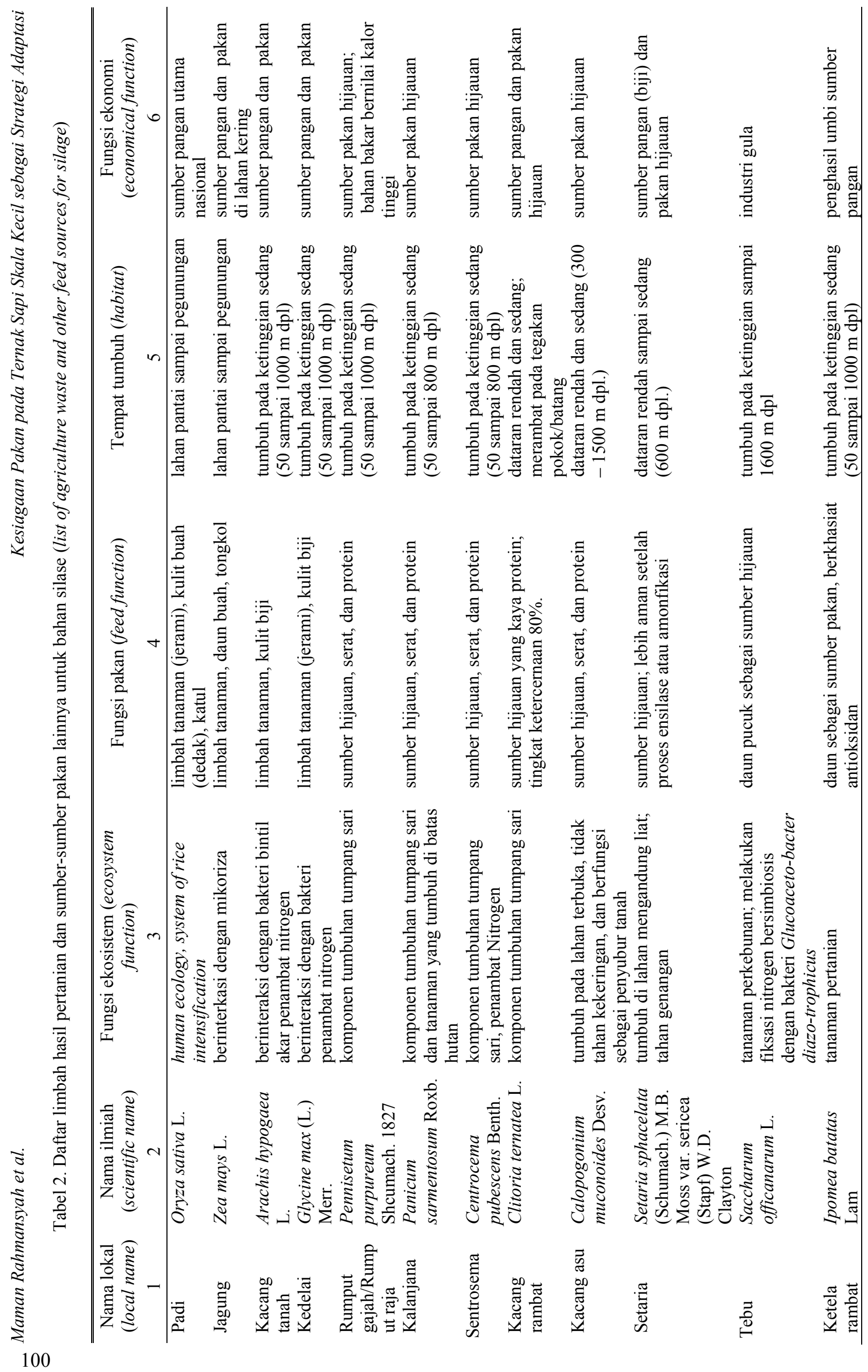




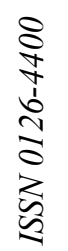

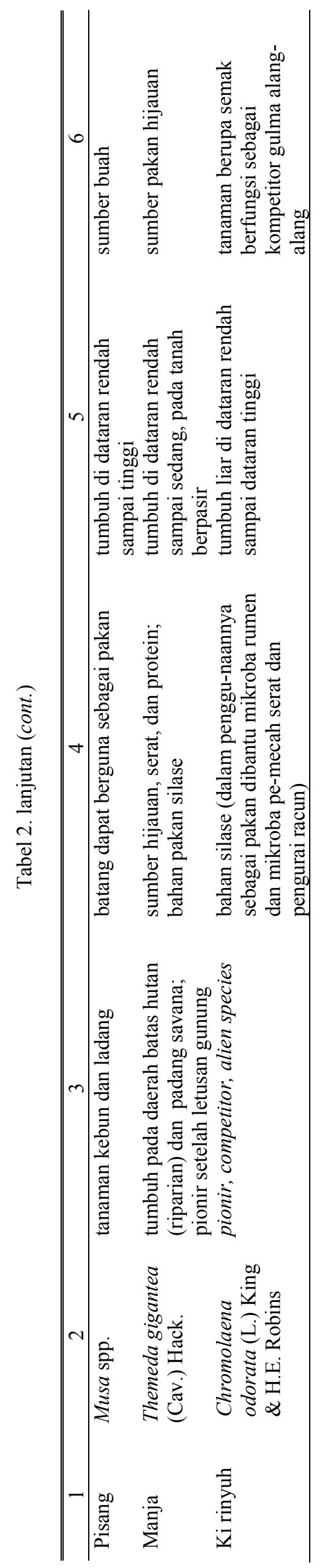

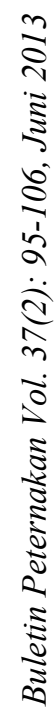



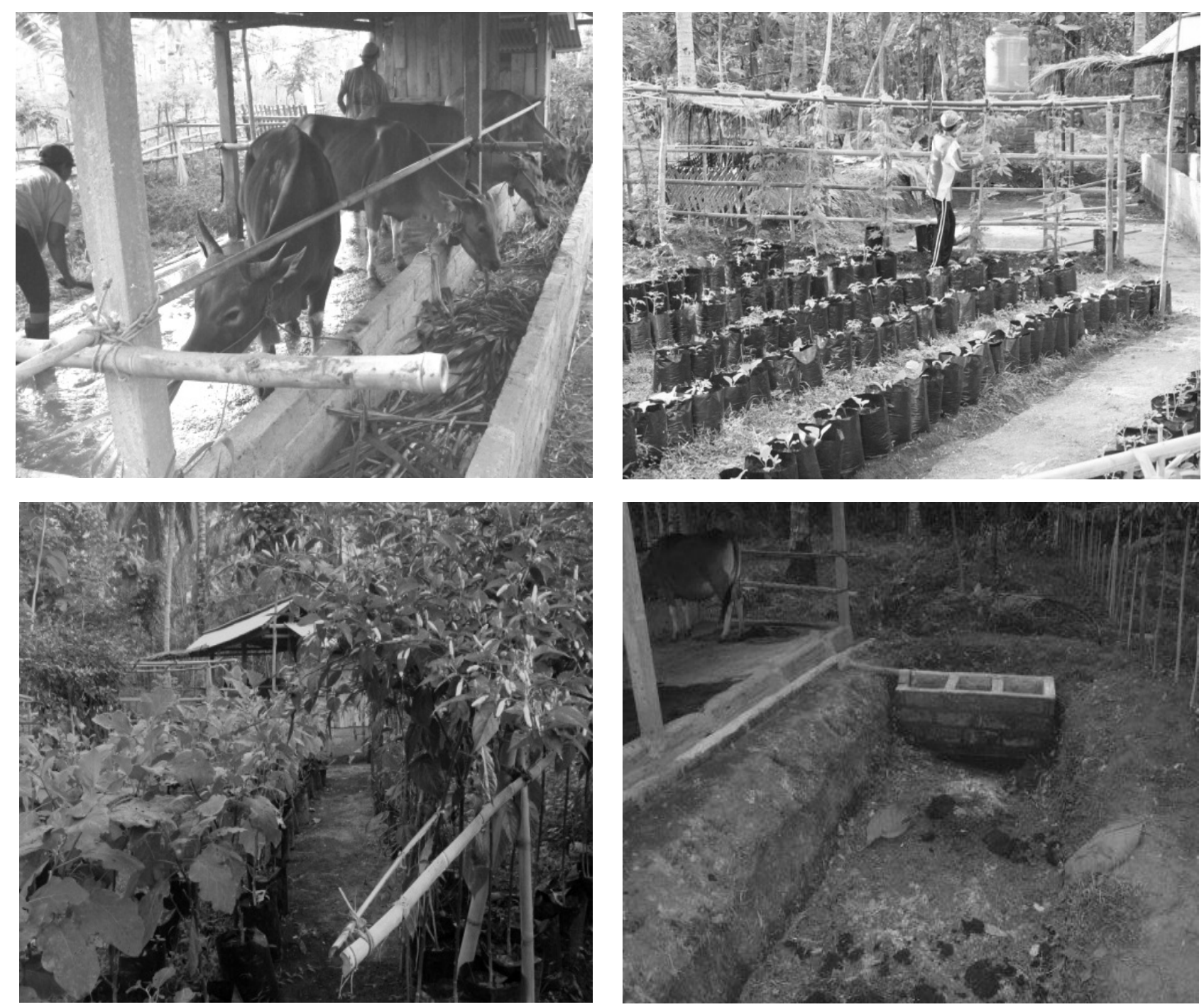

Gambar 1. Model kandang bersih untuk percontohan empat ekor sapi dengan kelengkapan tempat tampungan kotoran dan urine secara terpisah, dan didukung oleh $400 \mathrm{~m}^{2}$ lahan untuk tanaman pakan dan hortikultura (models of clean cowshed for four cow accomplished with receiving pool for its urine and fecal separately, and sustained with $400 \mathrm{~m}^{2}$ lands for grass cultivation and horticulture).

boleh terlepas dari dukungan pemerintah. Menurut Sutika (2011), program SIMANTRI pada dasarnya lebih menekankan kepada suatu upaya mandiri. Tujuannya untuk menstimulasi petani yang memelihara sapi menjadi mempunyai managemen perencanaan, berhitung, dan berorientasi pasar yang memihak petani. Di balik kegiatan tersebut terdapat capaian yang penting yaitu terkonsepnya suatu upaya konservasi terhadap genetika ras sapi Bali.

Kegiatan yang diprogramkan oleh Pemda Nusa Tenggara Timur (NTT) pada dasarnya sama seperti apa yang diupayakan di Bali. Manek (2010) menyatakan bahwa Pemda membuat konsep kegiatan yang mengacu pada perimbangan daya dukung alam yang dimiliki. Pembangunan Desa/Kelurahan Mandiri Anggur Merah (Anggaran untuk Rakyat Menuju Sejahtera) yang dimulai sejak 2011 terhadap 287 Desa/Kelurahan, dengan fokus untuk melaksanakan empat program yaitu pengembangan jagung, pengembangan ternak, pengembangan koperasi, dan pengembangan cendana. Nana (2008) serta Ratnawaty dan Fernandez (2009) telah memberikan dukungan lebih awal pada program tersebut khususnya pada bidang pengembangan peternakan sapi.

Program pengembangan jagung sangat terkait dengan keberhasilan pengembangan program ternak sapi di NTT. Dalam pelaksanaannya, perlu suatu strategi yang sejalan dengan pengalaman petani dalam teknis beternak yang sebenarnya telah menjadi kegiatan keseharian mereka. Pendekatan dan pendampingan diperlukan untuk mengubah pola sikap beternak yang telah tertanam sejak awal, yang sebenarnya masih memerlukan suatu perubahan, supaya petani sendiri menjadi terbuka niatnya untuk mengembangkan dirinya lebih jauh. 


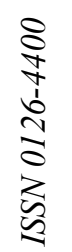

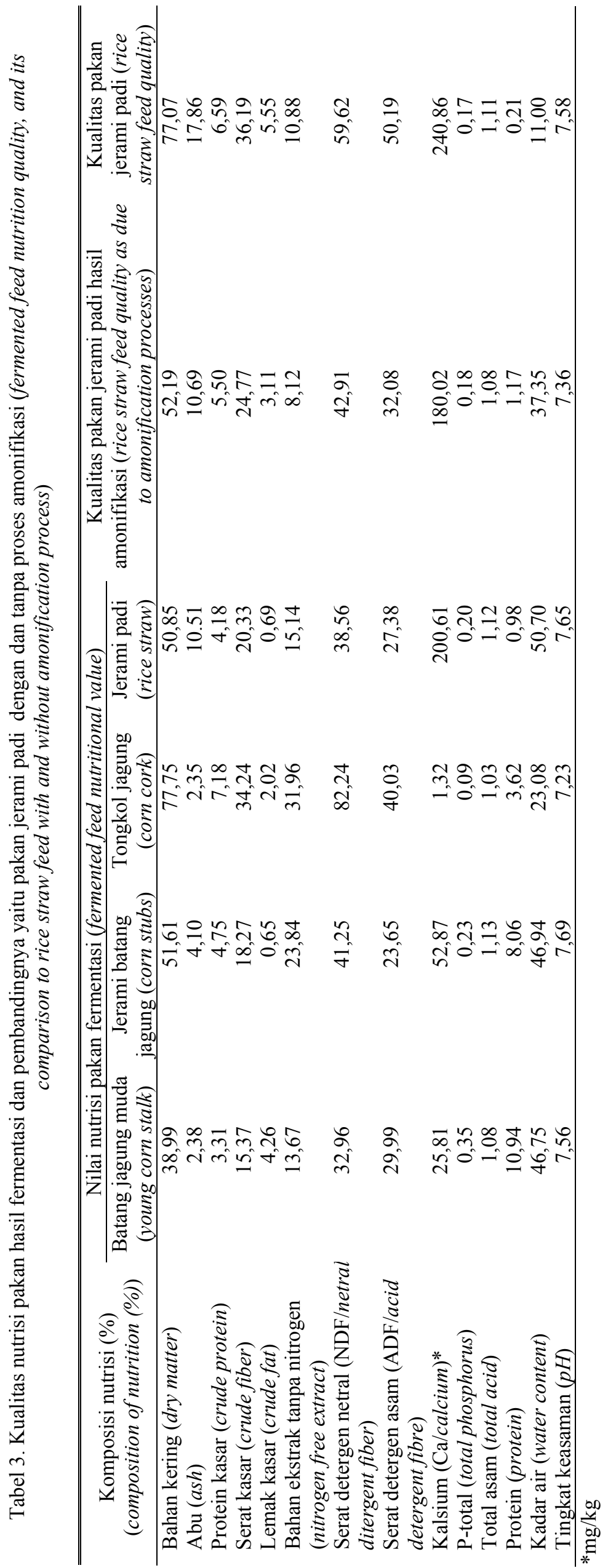




\section{Praktek pembuatan pakan}

Teknologi pembuatan pakan ditujukan kepada petani yang belum tersentuh oleh informasi tersebut. Kasus ini dijumpai pada beberapa wilayah survei di Provinsi Bali dan NTT. Keterlambatan penyerapan informasi lebih diakibatkan karena sikap petani yang cenderung menunggu atau pada beberapa kasus memang belum tersentuh program pembinaan yang ada. Peningkatan ketertarikan petani kepada pengembangan program harus dipandu dengan kegiatan yang nyata yang mudah ditiru dan diikuti. Pembuatan pakan silase memiliki kesamaan prinsip dengan pembuatan makanan tradisional, sehingga akan lebih mudah dipahami oleh kalangan petani dan peternak (Mould et al., 2005). Pembuatan silase dari limbah tanaman telah dipraktekkan dan hasilnya tertera pada Tabel 3 .

\section{Ragam protein pembangun tubuh ternak}

Pada musim kering, pakan ternak yang bisa diperoleh hanya berupa bahan pakan kering seperti jerami padi atau pohon jagung. Pola pakan ini sebagai suatu pola adaptasi yang dapat diterapkan pada pengelolaan ternak di musim kering karena keterbatasan hijauan. Pemberian pakan dengan bahan pakan kering akan menggurangi efisiensi serapan pakan karena pasokan protein ke dalam tubuh ternak menjadi terbatas. Pada kondisi seperti ini diperlukan asupan (pakan) berupa protein dari sumber lain seperti yang terkandung pada tepung sereal jagung (corn glutein meal) atau bekatul. Tambahan pakan berupa tepung tersebut diberikan sebanyak $2 \%$ dari bobot tubuh sapi peliharaan, atau sebanyak $4 \%$ pada sapi laktasi (perah) yang perlu diberikan untuk melengkapi kebutuhan. Menurut Hart et al. (2008), tambahan pakan tersebut akan mempengaruhi tingkat kemampuan mencerna oleh rumen sapi sehingga dapat mendukung tingkat asupan protein oleh tubuhnya. Pola manajemen pakan seperti ini merupakan teknologi yang dapat digunakan di dalam mengembangkan pola adaptasi akibat perubahan iklim, sehingga produktivitas ternak dapat dipertahankan.

Konsep adaptasi pada kegiatan ternak skala kecil berbasis keragaman biodiversitas tumbuhan lahan kering yang dapat dikembangkan adalah dengan memanfaatkan ketersediaan pakan hijauan dari tumbuhan hutan dan kebun atau ladang seperti tumbuhan leguminosa (Acacia leucophloea, Calliandra calothyrsus, Glirisidia sepium, Leucaena leucocephala, Sesbania grandiflora, Paraserianthes falcataria, Pterocarpus indicus, dan Tamarindus indica) dan non-leguminosa (Artcarphus heterophyllus, Chromolaena odorata, Ficus glauca, Gmelina arborea, Lannea grandis, Swietenia macrophylla, dan Zizyphus timoriensis).
Sumberdaya tersebut tersedia di lingkungan pedesaan (Rook et al., 2004).

\section{Kesimpulan}

Penguasaan teknis beternak sapi perlu dipahami oleh petani (kecil) di pedesaan untuk mendukung program nasional kemandirian swasembada daging sapi tahun 2014. Kontribusi peternak kecil menjadi konsisten apabila memperoleh dukungan pemasaran hasil. Banyak potensi yang bisa dikembangkan secara kolektif melalui kemitraan. Kelembagaan yang dibentuk semestinya dibangun dari petani yang menentukan arah dalam membangun kelompoknya karena mereka paham akan kebutuhan mereka sendiri di dalam mengembangkan usaha ternaknya. Kegiatan dengan resiko yang minimal dan capaian yang maksimal merupakan langkah yang strategis di dalam setiap pelaksanaan program. Pemanfaatan sumberdaya hayati sebagai sumber pakan dapat saja menghadapi kendala karena faktor alam yang akan lebih sulit diatasi dibandingkan dengan upaya memperbaiki kesalahan karena faktor manusia. Demikian pula pada kegiatan yang telah dilaksanakan sebagai praktek desiminasi teknologi pakan berbasis mikrobia fungsional, dan penghimpunan data dari kedua wilayah observasi ini sehingga pada bagian akhir dapat disampaikan simpulan berikut: 1). Biodiversitas flora lokal belum tergali seluruhnya dan dimanfaatkan sebagai sumber pakan. Pemrosesan dengan teknologi silase memungkinkan sumber hijauan menjadi palatable, walau sebelum proses ensilase tidak berfungsi sebagai pakan. 2). Teknologi silase memanfaatkan mikrobia fungsional (Lactobacillus plantarum dan mikrobia fungsional GRAS) sudah tepat diterapkan kepada petani peternak di wilayah lokasi kegiatan yang belum terjamah oleh informasi pengembangan ternak secara umum, atau pengembangan pakan secara khusus. 3). Upaya penyediaan pakan melalui pola pertanian terintegrasi (integrated farming system) menciptakan siklus energi (karbon) yang pendek, serta memperkecil emisi gas metana dan karbon dioksida. 4). Konsep pemberdayaan mikrobia fungsional dan pemanfaatan kelimpahan sumberdaya flora lokal berpeluang diterapkan di dalam mendukung praktek adaptasi pada kegiatan usaha ternak sapi skala kecil.

\section{Ucapan Terima Kasih}

Kegiatan ini dibiayai melalui kegiatan Proyek Prioritas Nasional melalui Program Aksi Bidang Lingkungan Hidup dan Pengelolaan Bencana, Tahun Anggaran 2012, Pusat Penelitian Geoteknologi LIPI. Ucapan terima kasih disampaikan 
kepada Pimpinan/Koordinator dan Pengelola Kegiatan Proyek PN-9 yang mendukung sepenuhnya mulai dari persiapan sampai pelaksanaan kegiatan.

\section{Daftar Pustaka}

ACIAR SADI. 2009. Hijauan Pakan Ternak untuk Ketahanan Pangan dan Peningkatan Penghasilan : Pengintegrasian tanaman legume ke dalam sistem budidaya jagung di Timor Barat. Lembar Fakta Program ACIAR.

Akar, S. 1996. Daun singkong dan pemanfaatannya terutama sebagai pakan tambahan. Wartazoa, 5: 21-25.

Bamualim, A. M. 2011. Pengembangan teknologi pakan sapi potong di daerah semi-arid Nusa Tenggara. Pengembangan Inovasi Pertanian 4: $175-188$.

Chadhokar, P. A. and H. R. Khantaraju. 1980. Effect of Gliricidia maculata on growth and breeding of Bannur ewes. Tropical Grassland, 14: 78-82.

Erowati, A. S. D. A. 2000. Penerapan teknologi silase hijauan makanan ternak (HMT) di Jombang Jawa Timur. Jurnal Teknologi Lingkungan 1: 184-188.

Elevitch, C. R. and H. I. Manner. 2006. Artocarpus heterophyllus Lam. (Jackfruit). Species Profiles for Pasific Island Agroforestry. Available at $\mathrm{http} / / \mathrm{www}$.traditionaltree.org. Accession date: May 25, 2012.

Elevitch, C. R. and L. A. J. Thomson. 2006. Hibiscus tiliaceus L. (Waru). Species Profiles for Pasific Island Agroforestry. Available at http//www.traditionaltree.org. Accession date: June 26, 2012.

Fiana, Y., I. Sulistyono, S. Wibowo, T. Munawarah, L. K. Kristianto, dan M. B. Nappu. 2004. Usahatani terpadu antara tanaman pangan dan ternak sapi sebagai penghasil bakalan. Seminar Nasional Sistem Integrasi TanamanTernak. Denpasar.

Hart, K. J., D. R. Yanez-Ruiz, S. M. Duval, N. R. McEwan and C. J. Newbold. 2008. Plant extracts to manipulate rumen fermentation. Anim. Feed Sci. Technol. 147: 8-35.

Janzen, H. H. 2011. What place for livestock on a re-greening earth? Anim. Feed Sci. Technol. 166: 783-796.

Joker, D. 2002. Pterocarpu indicus Willd. (Angsana). Informasi Singkat Benih. Direktorat Perbenihan Tanaman Hutan, Departemen Kehutanan.
Manek, D. 2010. Peluncuran Program Desa Mandiri. Pemerintah Daerah Nusa Tenggara Timur. Available at http://www.bappeda. nttprov.go.id. Accsession date: 12 Juni, 2012.

Mullik, M. L. and B. Permana. 2009. Improving growth rate of Bali cattle grazing native pasture in wet season by supplementing high quality forages. Indo. J. Anim. Vet. Sci. 14: 192-199.

Mould, F. L., K. E. Kliem, R. Morgan and R. M. Mauricio. 2005. In vitro microbial inoculum. A review of its function and properties. Anim. Feed Sci. Technol. 123: 31-50.

Murgueitioa, E., Z. Calle, F. Uribe, A. Calle and B. Solorio. 2011. Native trees and shrubs for the productive rehabilitation of tropical cattle ranching lands. For. Ecol. Manage. 261: 1654-1663.

Nana, L. 2008. Sapi paron Timor: Mengembalikan Timor sebagai gudang sapi. Available at http://leonardusnana-myfarm.blogspot.com/ 2008/03/sapi-paron-timor.html. Accession date: 13 Juni, 2012.

Pusat Penelitian dan Pengembangan Peternakan. 2010. Rekomendasi Teknologi Peternakan dan Veteriner Mendukung Program Swasembada Daging Sapi (PSDS) Tahun 2014. Badan Penelitian dan Pengembangan Pertanian.

Ratnawaty, S. dan P. T. Fernandez. 2009. Perbaikan kualitas pakan sapi melalui introduksi leguminose herba dalam menunjang program kecukupan daging nasional di Kabupaten Timor Tengah Selatan. Seminar Nasional Teknologi Peternakan dan Veteriner, Puslitbangnak Bogor. Hal: 107-112.

Risdiono, B., B. Haryanto, D. P. Nurhayati and B. Setiadi. 2009. Availability and utilization of forage resources for smallscale farm in Indonesia. In Proceedings of the International Seminar on Sustainable Management and Utilization of Forage-Based Feed Resources for Small-Scale Livestock Farmers in Asia, Lembang, Indonesia. Pp: 57-64.

Rook, A. J., B. Dumont, J. Isselstein, K. Osoro, M. F. Wallis De Vries, G. Parente and J. Mills. 2004. Matching type of livestock to desired biodiversity outcomes in pastures - a review. Biological Conservation 119: 137-150.

Salazar, R. and D. Jøker. 2001. Ceiba pentandra (L.) Gaertn. Informasi Singkat Benih. Direktorat Perbenihan Tanaman Hutan, Departemen Kehutanan. 
Sumarsono. 2006. Peran Tanaman Pakan dalam Intervensi Pertanian Berwawasan Lingkungan. Silaturahmi Ilmiah Internal Fakultas Peternakan Universitas Diponegoro Semarang, 29 Maret 2006.

Sutika, I. K. 2011. Simantri jadi pusat pembibitan sapi Bali. Available at http://bali.antaranews. $\mathrm{com} /$ berita/12113/simantri-jadi-pusatpembibitan-sapi-bali. Accession date: 1 Juni, 2012.

Thomson, L. A. J. 2006. Pterocarpus indicus Willd. (Narra). Species Profiles for Pasific Island Agroforestry. Available at www.traditionaltree.org. Accession date: June 4, 2012.
Ukanwoko, A. I. and N. C. Igwe. 2012. Proximate composition of some grass and legume silages prepared in a humid tropical environment. International Research Journal of Agricultural Science and Soil Science 2: 068-071.

Whistler, W. A. and C. R. Elevitch. 2006. Erythrina variegata L. (Dadap). Species Profiles for Pasific Island Agroforestry. Available at http://www.traditionaltree.org. Accession date: June 27, 2012.

Winugroho, M., Y. Widiawati, dan C. Talib. 2009. Potensi tanaman Chromolaena odorata sebagai pakan ruminansia. Prosiding Seminar dan Lokakarya Nasional Usaha Ternak Kerbau. Tana Toraja, 24-26 Oktober 2008. Bogor. Hal: 41-44. 